F. Hochhauser ${ }^{1}$, W. Ernst ${ }^{2}$, R. Rauch ${ }^{2}$, R. Vallant ${ }^{1}$, N. Enzinger ${ }^{1}$

\title{
INFLUENCE OF THE SOFT ZONE ON THE STRENGTH OF WELDED MODERN HSLA STEELS
}

\section{UTICAJ MEKE ZONE NA ČVRSTOĆU ZAVARENIH MODERNIH ČELIKA POVIŠENE ČVRSTOĆE}

\author{
Originalni naučni rad / Original scientific paper \\ UDK / UDC: Weld World (2014) 58:491-497; \\ DOI 10.1007/s40194-014-0132-0 \\ Rad primljen / Paper received: \\ Januar 2015.
}

Prevod izvornog rada na srpski jezik: Milica Antić,dipl.ing

Key words: Soft zone; constraint effect; HSLA Steel; Gas Metal Arc Welding; TMCP

\begin{abstract}
This study investigates the influence of softening in the heat affected zone of welds and the constraint effect on the transverse tensile strength of amicroalloyed,thermomechanicallycontrolled processed (TMCP) high strength steel grade. The welding was performed by MAG-Puls with three different levels ofenergy input to establish soft zones with varied extensions. Furthermore the thickness of the samples was reduced by milling to investigate the constraint effect at increased ratios of width of the soft zone to thickness on the transverse tensile strength of the welds. Although this modern steel is based on different conceptsand shows significantly different behaviour, (also with respect to weldability), in comparison to with classical quenched and tempered (QT) steels, it was found in this work that the established criteriafor the restriction of the soft zone width still can be applied.
\end{abstract}

\section{INTRODUCTION}

Modern hot rolled high strength low alloy (HSLA) steel grades are applied in a wide range, e.g. for construction machines and cranes, automotive and truck industry, pipelines, construction engineeringand shipbuilding. [1,2,3].

These types of steel are microalloyed with $\mathrm{Ti}, \mathrm{Nb}$ and $\mathrm{V}$ and are produced by a thermomechanical controlled process (TMPC). They are characterized by increased strength and toughness together with low carbon equivalents and therefore excellent weldability,

\author{
Adresa autora / Author's address: \\ ${ }^{1}$ Graz University of Technology, Inst. for Materials Science and \\ Welding, Kopernikusg. 24, 8010 Graz, Austria \\ ${ }^{2}$ Voestalpine Stahl GmbH, Linz, Austria
}

Ključne reči: Meka zona, efekat ograničenja; čelici povišene čvrstoće; zavarivanje u zaštiti gasa; TMCP

\begin{abstract}
APSTRAKT
U ovoj studiji se istražuje uticaj omekšavanja u zoni uticaja toplote zavarenog spoja i efekta ograničenja na poprečnu zateznu čvrstoću, mikrolegiranih, termomehanički kontrolisanim postupcima obrađenih (TMCP) čelika povišene črstoće. Zavarivanje je sprovedeno pomoću MAG/MIG impulsnog postupka sa tri različita nivoa unosa energije kako bi se stvorile meke zone sa različitim izduženjima. Šta više, debljina uzoraka je smanjena glodanjem da bi se istražio efekat ograničenja pri rastućem odnosu širine meke zone i debljine, na poprečnu zateznu čvrstoću zavarenog spoja. Mada su ovi moderni čelici zasnovani na različitim konceptima i pokazuju značajno različito ponašanje (takođe i vezano za zavarljivost) u poređenju sa klasičnim kaljenim i otpuštenim (QT) čelicima, ustanovljeno je da se uspostavljeni kriterijumi za ograničenje širine meke zone još uvek mogu primeniti.
\end{abstract}

\section{UVOD}

Moderni, vruće valjani, niskolegirani čelici povišene čvrstoće (HSLA) se široko primenjuju, na pr. za konstrukcije mašina i kranova, industriji automobile i kamiona, cevovodima, građevinarstvu i brodogradnji. $[1,2,3]$.

Ovi tipovi čelika su mikrolegirani sa $\mathrm{Ti}, \mathrm{Nb}$ i $\mathrm{V}$ a proizvode se termomehanički kontrolisanim procesom (TMPC). Karakterišu se istovremenom povećanom čvrstoćom i žilavošću uz mali ugljenikov ekvivalent i zato odličnom zavarljivošću, 
especially in sense of reduced preheating requirements and reduced susceptibility to cold cracking $[1,2,4]$.

To enable such outstanding and in some degree contradictory properties it is necessary to optimize the contributions of the basic strengthening mechanisms [1,2]:
$\Rightarrow$ solid solution strengthening by substitutional and interstitial elements like $\mathrm{Mn}, \mathrm{Si}, \mathrm{C}$ or $\mathrm{N}$
$\Rightarrow$ grain refinement
$\Rightarrow$ precipitation strengthening
$\Rightarrow$ transformation strengthening
$\Rightarrow$ dislocation strengthening

The contributions of the strengthening mechanisms are controlled by steel chemistry and thermomechanical treatment in combination with controlled cooling. During hot rolling the recrystallization of the deformed austenite is delayed by soluted microalloying elements $\mathrm{Ti}$ and $\mathrm{Nb}$ and its precipitations as carbonitrides. The deformed austenite transforms after finishingrolling into dislocation enriched fine grained transformation products. The types and amounts of resulting transformation products like ferrite, bainite or martensite depend on the cooling patterns and amount of transformation retarding elements (e.g. $\mathrm{C}, \mathrm{Mn}, \mathrm{Ni}, \mathrm{Mo}, \mathrm{B})$. The amount of precipitation hardening is achieved by titanium-niobium carbonitrides and vanadium carbides $[1,2,4]$.

It is not possible to obtain or restore the properties achieved by TMCP by a thermal heat treatment after hot rolling. Therefore, it is not surprising that softening may occur in the heat affected zone (HAZ) of welds, especially at increased energy input. This local softening does not however necessarily impair the global strength due to the constraints of the stronger weld metal and unaffected base metal [2].

For conventional steels a criterion was established in the 1970ies which suggests that the width of the soft zone should not exceed $25 \%$ of the welded plate thickness [5]. This study focuses on the influence of softening in the heat affected zone of welds and the constraint effect on the transverse tensile strength of a thermomechanically rolled and microalloyed high strength steel grade. Subsequently to a literature review, experimental results of welds of a TMCP steel with a minimum yield strength of $700 \mathrm{MPa}$ is given. The welding was performed by gas metal arc welding with three different levels of energy input to establish soft zones with varied extensions. posebno u smislu smanjenja zahteva za predgrevanjem i smanjene osetljivosti na hladne prsline. $[1,2,4]$.

Da bi se omogućila takva izvanredna i u nekom stepenu, kontradiktorna svojstva, neophodno je optimizovati doprinos osnovnih mehanizana ojačanja [1,2]:

$\Rightarrow$ Ojačavanje čvrstim rastvorom, supstitucijskim i intersticijskim elementima kao što su $\mathrm{Mn}$, $\mathrm{Si}, \mathrm{C}$ ili N

$\Rightarrow$ Rafinacija zrna

$\Rightarrow$ Taložno otvrdnjavanje

$\Rightarrow$ Ojačavanje transformacijom

$\Rightarrow$ Dislokacino ojačavanje

Doprinosi mehanizama ojačavanja kontrolišu se hemijskim sastavom čelika i termomehaničke obrade u kombinaciji sa kontrolisanim hlađenjem. Tokom toplog valjanja, rekristalizacija deformisanog austenita je zakasnela zbog rastvorenih mikrolegirajućih elemenata $\mathrm{Ti}$ i $\mathrm{Nb}$ i njihovih taloga kao karbonitrida. Deformisani austenit se transformiše posle završnog valjanja u finozrne proizvode transformacije, obogaćene dislokacijama. Tipovi i udeli rezultujućih proizvoda transformacije kao što su ferit, beinit ili martenzit, zavisi od načina hlađenja i udela elemenata koji usporavaju transformaciju (na pr. C, Mn, Ni, Mo, B). Udeo taložnog otvrdnjavanja se postiže titanniobijum karbonitridima i vanadijum karbidima $[1,2,4]$.

Nije moguće postići ili vratiti osobine postignute pomoću TMCP nekom termičkom obradom posle vrućeg valajanja. Zbog toga nije iznenađujuće to, da se omekšavanje može javiti u zoni uticaja toplote (ZUT) zavarenih spojeva, posebno pri povećanoj količini unete energije. Ova lokalna omekšavanja ne moraju međutim, da imaju obavezni uticaj na ukupnu čvrstoću zato što postoje ograničenja jačim metalom šava i osnovnim materijalom koji nije pod uticajem toplote [2].

$\mathrm{Za}$ konvencionalne čelike, kriterijum koji je ustanovljen 1970-ih predlaže da širina meke zone ne prelazi $25 \%$ debljine zavarenog lima [5]. Ova studija je usmerena na uticaj omekšavanja u zoni uticaja toplote zavarenih spojeva i efekat ograničenja na poprečnu zateznu čvrstoću temomehanički valjanog i mikrolegiranog čelika povišene čvrstoće.Prema pregledu literature, dati su eksperimentalni rezultati zavarenih spojeva TMCP čelika sa minimalnim naponom tečenja od $700 \mathrm{MPa}$. Zavarivanje je izvedeno zavarivanjem u zaštiti gasa sa tri različita nivoa unete energije radi uspostavljanja mekih zona sa različitim izduženjima. 
Furthermore, the thickness of the samples was reduced by milling to investigate the constraint effect at increased relative thicknesses of the soft zone $X_{S z}$ (ratio of width of the soft zone to plate thickness) on the transverse tensile strength of the welds.

\section{LITERATURE REVIEW}

A description of possible softening phenomena in the HAZ of low alloyed steel welds is followed by a survey of investigations concerning the impact of a soft zone on the static transversal strength of welds.

\section{Softening phenomena in the HAZ of low alloy steel welds}

The amount of softening in the HAZ of steel welds depends on the applied strengthening mechanisms and their susceptibility to and behaviour at thermal heat treatment.The reduction of strength in the adjacent region to welds is observed for steel types whose strength is based of non-equilibrium microstructure and consist of metastable transformation microstructure or which are in a condition which cannot be restored by a thermal heat treatment. Precipitations could contribute to softening by their coarsening or could balance the decrease in strength by formation of new ones.

In this section softening effects in the HAZ of quenched and tempered steels (QT) are compared with that of microalloyed TMCP steels. Softening of further low alloyed steel types e.g. dual phase steels (DP 980) are discussed elsewhere [6].

The softening effects within the soft zone can be classified according to the occurring peak temperature: tempering softening is present below and transformation softening above the $A_{1}$ temperature. This classification originated from investigation of QT structural steels by Mennen [7] and Müller [8].

Microstructure of QT steels usually consists ofa metastable transformation microstructure ofmartensite or bainite, which is tempered during production process after the hardening treatment at temperatures below the transformation point $A_{1}$ [8]. These tempering processes include carbon rejection of the supersaturated martensite, transformation of metastable carbides to stable ones or coarsening / spheroidization of carbides and recrystallization of grains [4]. Comparable tempering processes occur in the HAZ of welds. The possibility to stabilize the strength by means of recipitation hardening by carbide formation of other alloying elements like $\mathrm{Cr}, \mathrm{V}$ or $\mathrm{Ti}$ was mentioned in [7].
Šta više, debljina uzoraka je smanjena glodanjem kako bi se istraživao efekat ograničenja na povećanoj debljini meke zone $X_{S Z}$ (odnos širine meke zone i debljine lima) na poprečnu zateznu čvrstoću zavarenih spojeva.

\section{LITERATURNI PREGLED}

Opis moguće pojave omekšavanja u ZUT zavarenih spojeva na niskolegiranim čelicima praćen je pregeledom istraživanja koja se odnose na uticaj meke zone na statičku poprečnu čvrstoću zavarenih spojeva.

\section{Pojava omekšavanja u ZUT zavarenih spojeva niskolegiranog čelika}

Udeo omekšavanja ZUT zavarenih spojeva čelika zavisi od primenjenih mehanizama ojačavanja i njihove osetljivosti na ponašanje pri termičkim obradama. Smanjenje čvrstoće u susednoj oblasti zavarenog spoja zapaženo je kod tipova čelika čija je čvstoća zasnovana na neravnotežnoj strukturi koja se sastoji se od mikrostrukture metastabilne transformacije u uslovima koji se ne mogu povratiti termičkim obradama. Talozi mogu da doprinesu omekšavanju zbog svoje gruboće ili mogu da balansiraju smanjenje čvrstoće stvaranjem novih.

U ovom delu su omekšavajući efekti u ZUT kaljenog i otpuštenog (QT) čelika upoređeni sa mikrolegiranim TMCP čelicima. O omekšavanju narednih niskolegiranih čelika na pr. dvofazni čelici (DP 980) diskutovano je negde drugde [6].

Efekti omekšavanja unutar meke zone mogu se klasifikovati prema vršnoj temperaturi koja se javlja: omekšavanje žarenjem je prisutno ispod i omekšavanje transformacijom iznad $\mathrm{A}_{1}$ temperature. Ovu klasifikaciju koja je nastala iz istraživanja QT konstrukcionih čelika dali su Mennen [7] i Müller [8].

Mikrostruktura QT čelika se obično sastoji od mikrostrukture metastabilne transformacije, martenzita ili beinita, koji sužareni tokom procesa proizvodnje posle kaljenja na temperaturama ispod tačke transformacije $A_{1}$ [8]. Ovi procesi žarenja obuhvataju odbacivanje ugljenika iz superzasićenog martenzita, transformaciju metastabilnih karbida u stabilne ili ogrubljivanje/sferoidizaciju karbida i rekristalizaciju zrna [4]. Uporedivi procesi žarenja javljaju se u ZUT zavarenih spojeva. Mogućnost da se stabilizuje čvrstoća preko taložnog ojačavanja stvaranjem karbida drugih legirajućih elemenata poput $\mathrm{Cr}$, V ili Ti pomenuta je u [7]. 
If the hardened microstructure is exposed to temperatures above $A_{1}$ temperatureand cooled subsequently to welding, the austenite decomposes to microstructures with reduced strength e.g. ferrite or bainite [9]. It has to be noted that this behaviour strongly depends on the chemical composition of the steel and therefore its transformation behaviour.

As mentioned above, TMCP steels are susceptible to softening in the HAZ too $[2,10,11]$. Wallner et al [11] schematically compared the formation of soft zones for QT and TMPC steels with comparable yield strength, see Fig. 1. Tempering softening is less pronounced for microalloyed TMCP steels due to a beneficial precipitation hardening effect and less transformation hardened microstructure. Nevertheless, overageing of already existing precipitations or recovery of dislocations or other defects could possibly lower the hardness in the region which was exposed to temperatures below A1 temperatur.
Ako se ovrdnuta mikrostruktura izlaže temeperaturama iznad $A_{1}$ temperature i hladi naknadno do zavarivanja, austenit se raspada na mikrostrukture koje smanjuju čvrstoću na pr. ferit ili beinit [9]. Važno je naglasiti da ova pojava jako zavisi od hemijskog sastava čelika i zbog toga, njegovih pojava transformacija.

Kao što je ranije pomenuto, TMCP čelici su takođe osetljivi na omekšavanje u ZUT $[2,10,11]$. Wallner $i$ $d r$. [11] su šematski uporedili nastajanje mekih zona kod QT i TMPC čelika sa sličnim naponom tečenja, videti sl. 1. Omekšavanje žarenjem je manje izraženo kod mikrolegiranih TMCP čelika usled povoljnog efekta precipitacionog ojačavanja i mikrostrukture otvrdnute sa manje transformacije. Ipak, preterano starenje već postojećeg taloga ili oporavak dislokacija ili drugih defekata mogu da smanje tvrdoću u oblasti koja je izložena temperaurama ispod $A_{1}$ temperature.

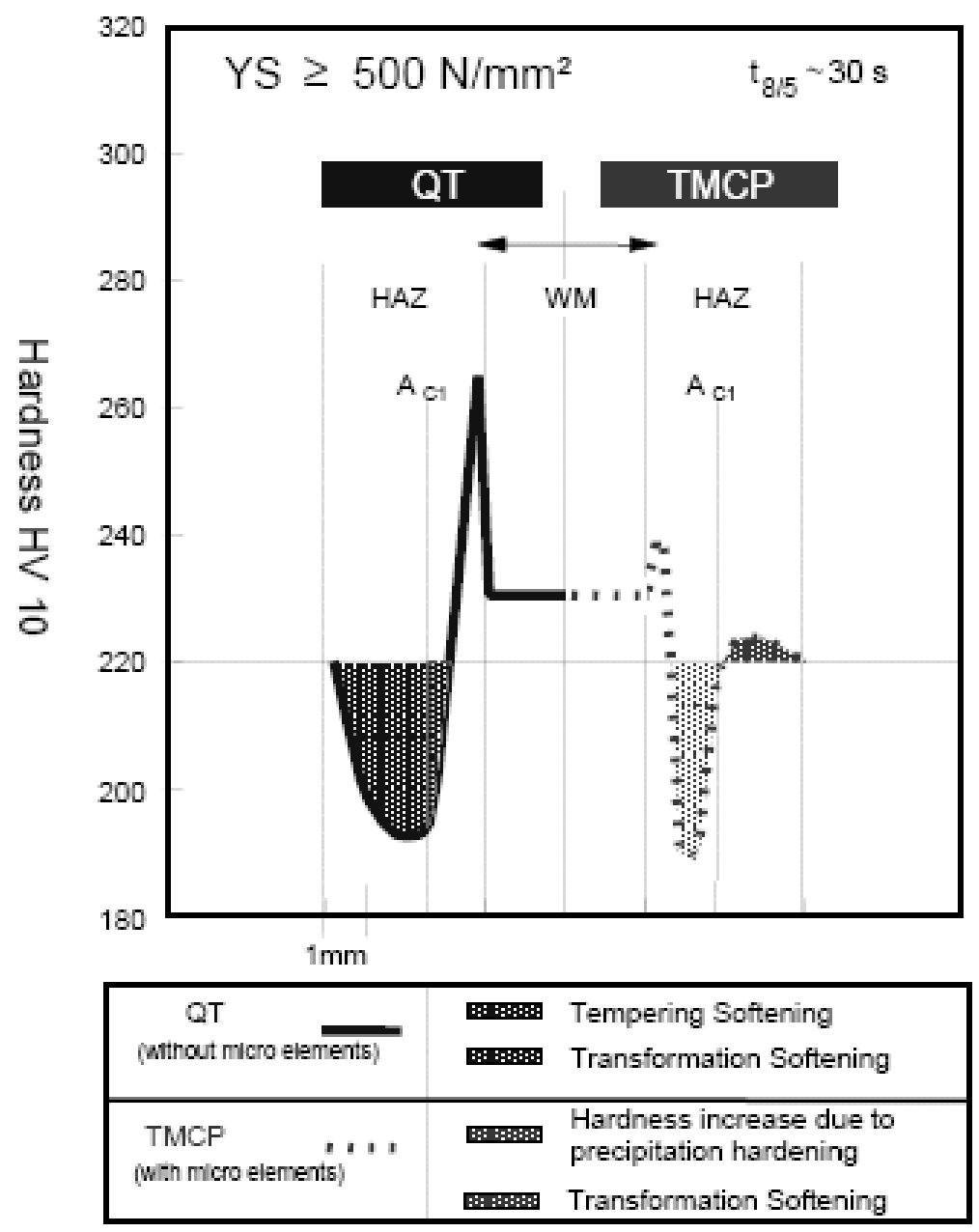

Fig. 1. Schematic comparison of the soft zone of a QT (left) and a TMCP steels (right) [11]

SI. 1. Šematsko upoređenje meke zone QT (levo) i TMCP čelika (desno) [11] 
Contrary, thermomechanically treated microstructure changes irreversible if the microstructure is exposed to temperatures above $A_{1}$ temperature (transformation softening). Whilst the subsequent cooling, the generated austenite transforms to microstructures with less defect density and coarser grain size.

Furthermore at low austenitizing temperatures, precipitations could not be dissolved sufficiently and re-precipitation as fine and strength improvement particles is not possible during the subsequent cooling [4]. The preservation of transformation strength effect during cooling of the HAZ region depends on the chemical composition and transformation retardation of the steel.

Summarized, softening in the HAZ of TMCP welds is mainly restricted to transformation softening. The resulting width of soft zone is smaller for TMCP steels in comparison to QT steels.

Strength of welds with a soft zone under quasi static transverse tension

First systematic investigations and analytic descriptions concerning the behaviour of welded joints including a soft interlayer under transverse tension were carried out by Shron and Bakshi [12] and Satoh and Toyoda [13,14]. Further developments were done by e.g. Ostsemin [15].

Recently finite element simulations of the problem were carried out by e.g. Rodrigues et al [16] or Mochizuki et al [17].

These investigations describe the stress state and deformation behaviour within the soft interlayer and strength of the entire sample under transverse tension. Main influencing factors are the ratio of width of the soft zone to the sample thickness, called relative thickness $X_{S z}$, and the differences in mechanical properties (yield strength, strain hardening, tensile strength) of the soft zone and the adjacent materials.

The tensile strength of the joint is continuously reduced with increasing relative thickness of the soft zone. Critical values of relative thickness which cause a significant strength loss of the weldment in comparison to the base material vary from 0.25 [11] to 1 [2]. These variations might be attributed to the differences in investigated materials and their mechanical properties.

Furthermore, influence of the sample cross section [14] and specimen size effects $[10,14]$ on the static tensile strengthwas reported.
Nasuprot tome, promene termomehanički obrađene mikrostrukture su nepovratne ako je mikrostruktura izložena temperaturama iznad $A_{1}$ temperature (transformaciono omekšavanje). Dodatnim hlađenjem, stvoreni austenit se transformiše u mikrostrukture sa manjom gustinom defekata i grubljim zrnom.

Šta više, pri niskim temperaturama austenitizacije, talozi ne mogu dovoljno da se rastvore i ponovno taloženje u obliku finih čestica koje povećavaju čvrstoću, nije moguće tokom dodatnog hlađenja [4]. Očuvanje efekta čvrstoće transformacijom, tokom hlađenja oblasti ZUT zavisi od hemijskog sastava iostataka transformacije čelika.

Zbirno, omekšavanje u ZUT zavarenih spojeva TMCP je uglavnom ograničeno na transformaciono omekšavanje. Rezultujuća širina meke zone je manja kod TMCP čelika u poređenju sa QT čelicima.

Čvrstoća zavarenih spojeva sa mekom zonom pod kvazi statičkim poprečnim zatezanjem

Prva sistematična istraživanja i analitički opis koji se odnosi na ponašanje zavarenih spojeva, uključujući meki međusloj pod poprečnim zatezanjem, sproveli su Shron i Bakshi [12] i Satoh i Toyoda [13,14]. Sledeći razvoj je uradio na pr. Ostsemin [15].

Nedavne simulacije konačnim elementima ovog problema sproveli su na pr.Rodrigues $i d r$. [16] or Mochizuki i dr. [17].

Ova istraživanja opisuju stanje napona i deformacija unutar mekog međusloja i čvrstoću celog uzorka pod poprečnim zatezanjem. Glavni uticajni faktori su odnos širine meke zone idebljine uzoraka, nazvan relativna debljina $X_{S Z}$, i razlike u mehaničkim osobinama (napon tečenja, deformaciono ojačavanje, zatezna čvrstoća) meke zone i okružujućeg materijala.

Zatezna čvrstoća spoja se kontinualno smanjuje sa porastom relativne debljine meke zone. Kritične vrednosti relativne debljine koje uzrokuju značajno smanjenje čvrstoće zavarene komponente u poređenju sa osnovnim materijalom variraju od 0.25 [11] do 1 [2]. Ove varijacije se mogu pripisati razlikama $u$ ispitivanim materijalima i njihovim mehaničkim osobinama.

Šta više, uticaj poprečnog preseka uzorka [14] i efekti veličine epruvete $[10,14]$ na statičku zateznu čvrstoću su saopšteni. 
Satoh and Toyoda [14] distinct between finite and infinite sample widths. At finite sample width the tensile strength is reduced with decreasing width. If infinite sample width, $W_{\text {inf, }}$ can be assumed the measured tensile strength is constant. The conditions of an infinite plate is given for $X_{S Z} \leq 1$ by $W_{\text {inf }}=5$ times sheet thickness and for $X_{s z}>1$ by $W_{\text {inf }}=5$ times width of soft zone. The infinite case would be existent in welded constructions and would reduce the impact of softening on the static strength.

The influence of strength properties of the weld metal (strength over-matching, even-matching or under-matching) and its geometrical extension was systematically investigated by Mochizuki et al. [17]

Strength over-matching and increased relative thickness of the weld metal (ratio of weld metal width to sample thickness) balance the influence of HAZ softening.

An additional negative influence of removal of weld reinforcement on the static strength ofweldments are mentioned in Ref. 10.

Summarizing important factors which influence the transversal tensile strength and plastic deformation can be grouped as follows

1.) geometry: extension in loading direction and geometric shape of the soft zone and the weld metal

2.) material: mechanical properties (yield strength, strain hardening, tensile strength) of base metal, weld metal and the different regions of the soft zone

These factors depend on the selected base metal, weld metal, the applied welding process and welding parameters and as well the dimensions and geometry of the joined component.

The influence of HAZ softening on further important properties of weld such as fatigue resistance and fracture toughness is discussed elsewhere e.g fatigue $[3,18]$, fracture toughness $[10,19]$.

\section{EXPERIMENTAL}

\section{Base metal}

The investigated steel type was a classical TMCP steelstrip, microalloyed with $\mathrm{Ti}, \mathrm{Nb}$ and $\mathrm{V}$. The microstructure consists mainly of bainite and ferrite. This type of steel derives its strength from grain refinement, precipitation hardening and a less amount of transformation hardening.
Satoh i Toyoda [14] prave razliku između konačne i beskonačne širine uzorka. $\mathrm{Na}$ konačnoj širini uzorka, zatezna čvrstoća se smanjuje sa smanjenjem širine. Kod beskonačne širine uzorka,

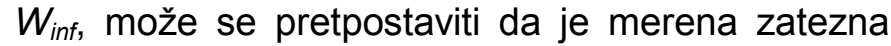
čvrstoća konstantna. Uslovi za beskonačni lim su dati za $X_{S Z} \leq 1$ pomoću $W_{\text {inf }}=5$ puta debljina ploče i za $X_{S z}>1$ by $W_{\text {inf }}=5$ puta širina meke zone. Beskonačni slučaj može da postoji u zavarenim konstrukcijama i dovodi do smanjenja uticaja omekšavanja statičke čvrstoće.

Uticaj osobina čvrstoće metala šava (veća čvrstoća "over-matching", slična čvrstoća "even-matching" ili niža čvrstoća "under-matching") i njihovo geometrijsko širenje je sistematski istraživao Mochizuki i dr. [17]

Veća čvrstoća "over-matching" i povećana relativna debljina metala šava (odnos širine metala šava i debljine uzorka) uravnotežavaju uticaj omekšavanja ZUT.

Dodatni negativni uticaj uklanjaja nadvišenja šava na statičku čvrstoću zavarenog elemenata pomenuti su u Ref. 10.

Sumarno prikazano, značajni faktori koji utiču na poprečnu zateznu čvrstoću i plastičnu deformaciju se mogu grupisati na sledeći način:

1.) geometrija: proširenje u pravcu opterećenja i geometrijski oblik meke zone metala šava

2.) materijal: mehaničke osobine (napon tečenja, deformaciono ojačavanje, zatezna čvrstoća) osnovnog materijala, metala šava i različitih oblasti meke zone

Ovi faktori zavise od odabranog osnovnog materijala, metala šava, primenjenog postupka zavarivanja i parametara zavarivanja kao i dimenzija i geometrijespojene komponente.

Uticaj omekšavanja ZUT na dalje značajne osobine zavarenog spoja kao što su otpornost na zamor i udarna žilavost,diskutovan je na drugim mestima, na pr. zamor [3,18], udarna žilavost $[10,19]$.

\section{EKSPERIMENT}

\section{Osnovni materijal}

Ispitivani tip čelika je klasična TMCP čelična traka, mikrolegirana sa $\mathrm{Ti}, \mathrm{Nb}$ i $\mathrm{V}$. Mikrostruktura se sastoji uglavnom od beinita iferita. Ovaj tip čelika razvija svoju čvrstoću iz rafinacije zrna, taložnog ojačavanja i malog udela transformacionog ojačavanja. 
Comparable chemical composition and mechanical properties can be seen in Table 1 and Table 2.
Uporedivi hemijski sastav i mehaničke osobine se mogu videti u tabelama 1 i 2.

\begin{tabular}{|c|c|c|c|c|c|c|c|}
\hline $\mathrm{C}$ & $\mathrm{Mn}$ & $\mathrm{Si}$ & $\mathrm{Nb}^{1}$ & $\mathrm{Ti}^{1}$ & $\mathrm{~V}^{1}$ & $\mathrm{Mo}$ & $\mathrm{B}$ \\
\hline$<0.12$ & $<2.10$ & $<0.60$ & $<0.09$ & $<0.22$ & $<0.20$ & $<0.50$ & $<0.005$ \\
\hline
\end{tabular}

Table 1. Chemical compositions according to EN 10149-2 (mass\%) [20]

Tabela 1. Hemijski sastav prema EN 10149-2 (mas.\%) [20]

$$
{ }^{1} \mathrm{Nb}+\mathrm{Ti}+\mathrm{V}<0.22
$$

\begin{tabular}{|c|c|}
\hline $\begin{array}{c}\text { Napon tečenja } \\
{[\mathrm{MPa}]}\end{array}$ & $\begin{array}{c}\text { Zatezna čvrstoća } \\
{[\mathrm{MPa}]}\end{array}$ \\
\hline$\geq 700$ & $750-950$ \\
\hline
\end{tabular}

Table 2. Mechanical properties according to EN 10149-2 [20]

Tabela 2. Mehaničke osobine prema EN 10149-2 [20]

\section{Welding experiments}

The welding was performed by gas metal arc welding with three different levels of energy input to establish soft zones with varied extensions. Two plates $(150 \times 500 \mathrm{~mm}, 6 \mathrm{~mm}$ thickness) were joined by single pass butt weldsat each energy input level. The configuration of the joint can be seen in Fig. 2 . The single-bevel groove was produced by milling. The two plates were fixed by chuck jaws with a gap of $1 \mathrm{~mm}$. Additionally small run-in and run-off plates at the beginning and the end of the joint were used.

A DC power source (Fronius TPS5000) in combination with an automatic straight-line travel carriage was used to perform the pulsed GMAW welding.

\section{Zavarivački eksperimenti}

Zavarivanje je izvedeno u zaštiti gasa sa tri različita nivoa unete energije kako bi se uspostavile meke zone različitih širina. Dva lima $(150 \times 500 \mathrm{~mm}, 6 \mathrm{~mm}$ debljine) su spojena jednoslojnim sučeonim spojevima pri svakom unosu energije. Konfiguracija spoja se može videti na sl. 2. Jednostrani žljeb je izrađen glodanjem. Dva lima su fiksirana čeljustima držača sa zazorom od $1 \mathrm{~mm}$. Dodatno su korišćene male uvodne i izlazne pločice za početak i završetak spoja.

Korišćen je izvor jednosmerne struje DC (Fronius TPS5000) u kombinaciji sa automatizovanom linijom za vođenje "traktora" za izvođenje pulzirajućeg MAG/MIG zavarivanja.
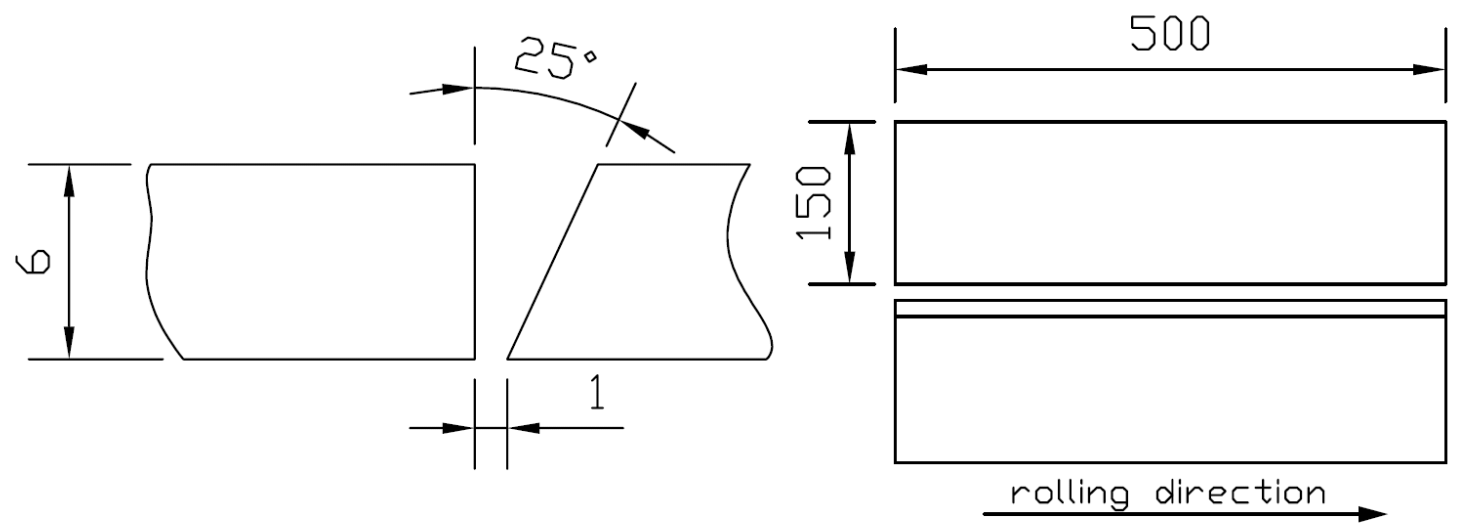

Fig. 1. Geometry of weld preparationand welded plates. Dimensions in $\mathrm{mm}$

SI. 2. Geometrija pripreme za zavarivanje i zavareni limovi. Dimenzije u $\mathrm{mm}$ 
The used filler metal was a medium alloy solid wire G $795 \mathrm{M}$ Mn4Ni1,5CrMo according to EN 12534 for shielded arc welding [21] with a diameter of $1.2 \mathrm{~mm}$. Typical chemical composition and the mechanical properties of the weld metal are shown in Table 3 and 4.
Korišćeni dodatni material je srednje legirana žica G 795 M Mn4Ni1,5CrMo prema EN 12534 za zavarivanje u zaštiti gasa [21] prečnika od $1.2 \mathrm{~mm}$. Tipični hemijski sastav i mehaničke osobine metala šava su prikazane u tabelama 3 i 4.

\begin{tabular}{|c|c|c|c|c|c|}
\hline $\mathrm{C}$ & $\mathrm{Si}$ & $\mathrm{Mn}$ & $\mathrm{Cr}$ & $\mathrm{Mo}$ & $\mathrm{Ni}$ \\
\hline 0.09 & 0.7 & 1.7 & 0.3 & 0.6 & 1.85 \\
\hline
\end{tabular}

Table 3 Typical chemical composition of filler material (mass \%) [22]

Tabela 3 Tipični hemijski sastav dodatnog materijala (mas. \%) [22]

\begin{tabular}{|c|c|}
\hline $\begin{array}{c}\text { Napon tečenja } \\
\text { [MPa] }\end{array}$ & $\begin{array}{c}\text { Zatezna } \\
\text { čvrstoća [MPa] }\end{array}$ \\
\hline$>770$ & $>880$ \\
\hline
\end{tabular}

Table 4 Mechanical properties of weld metal [22]

Tabela 4 Mehaničke osobine metala šava [22]

Shielding gas $\mathrm{M} 21\left(\mathrm{Ar}+18 \% \mathrm{CO}_{2}\right)$ according to $\mathrm{EN}$ 439 [23] was applied with a mass flow of $151 / \mathrm{min}$.

Three different energy input levels were achieved with constant average voltage of $22 \mathrm{~V}$ and average current of $210 \mathrm{~A}$ and three different weld speeds: $55 \mathrm{~cm} / \mathrm{min}, \quad 42.5 \mathrm{~cm} / \mathrm{min}$ and $30 \mathrm{~cm} / \mathrm{min}$. The calculated energy inputs andmeasured cooling times $t_{8 / 5}$ between 800 and $500^{\circ} \mathrm{C}$ are given in Table 5.
Zaštitni gas M21 ( $\left.\mathrm{Ar}+18 \% \mathrm{CO}_{2}\right)$ prema EN 439 [23] je primenjen sa protokom od 15l/min.

Tri različita nivoa unete energije su ostvarena sa konstantnom srednjom vrednosti od $22 \mathrm{~V}$ i srednjom jačinom struje od $210 \mathrm{~A}$ i tri različite brzine zavarivanja: $55 \mathrm{~cm} / \mathrm{min}, 42.5 \mathrm{~cm} / \mathrm{min}$ i $30 \mathrm{~cm} / \mathrm{min}$. Izračunate količine unete toplote i izmerena vremena hlađenja $t_{8 / 5}$ između 800 i $500^{\circ} \mathrm{C}$ date su u tabeli 5.

\begin{tabular}{|c|c|}
\hline $\begin{array}{c}\text { Uneta toplota } \\
{[\mathrm{kJ} / \mathrm{mm}]}\end{array}$ & $\begin{array}{c}\text { Vreme hlađenja } \mathrm{t}_{8 / 5} \\
{[\mathrm{~s}]}\end{array}$ \\
\hline 0.42 & 5.5 \\
\hline 0.53 & 8.5 \\
\hline 0.76 & 18.5 \\
\hline
\end{tabular}

Table 1 Energy input and measured cooling time $t_{8 / 5}$

Tabela 2 Uneta količina i merene vremena hlađenja $t_{8 / 5}$

\section{Characterization of the welds}

Cross sections of the weldments wereground, polished and etched with nital and investigated by means of light optical microscopy. Vickers hardness measurements according to ISO 6507-1 [24] were done to examine the decrease in hardness and width of the soft zone.

Flat bar tensiontest specimens according to EN 10002-1 [25] were machined from the weldments transverse to the weld direction. The width of the tensile specimen within measurement length was $20 \mathrm{~mm}$.

\section{Karakterizacija zavarenih spojeva}

Poprečni preseci zavarenih elemenata su brušeni, polirani i nagriženi nitalom i ispitani optičkim mikroskopom. Obavljena su merenja tvrdoće prema Vikersu prema ISO 6507-1 [24] kako bi se ispitalo smanjenje tvrdoće i širina meke zone.

Ravne okrugle epruvete za ispitivanje zatezanjem prema EN 10002-1 [25] su mašinski obrađene iz zavarenog elementa poprečno na pravac zavarivanja. Širina epruvete za zatezanje unutar merne dužine je $20 \mathrm{~mm}$. 
The welded specimens were groundon the root side and milled on the top side to create samples with sheet thickness between 2 and $6 \mathrm{~mm}$. This was done to achieve different relative thicknesses $X_{S Z}$ of the soft zone based on identical welding conditions. Furthermore samples without a machined top side were tested to clarify the influence of the weld reinforcement. Additionally tensile specimens of the base metal were produced to obtain reference values. Table 6 gives an overview of the conducted tensile test sand specimen conditions (thickness and top side condition).
Zavarene epruvete su brušene sa korene strane i glodane sa vršne strane kako bi se napravili uzorci širine ploča između 2 i $6 \mathrm{~mm}$. Ovo je urađeno kako bi se postigla različita relativna debljina $X_{S z}$ meke zone zasnovane na identičnim uslovima zavarivanja. Uzorci kod kojih nije glodanjem uklonjen višak sa gornje strane šava, ispitani su da bi se potvrdio uticaj nadvišenja šava. Dodatno su napravljene epruvete za zatezanje od osnovnog materijala za dobijanje referentnih vrednosti. $U$ tabeli 6 je dat pregled sprovedenih ispitivanja na zatezanje kao i uslovi za epruvete (debljina i uslov vrha spoja ).

\begin{tabular}{|c|c|c|c|c|}
\hline \multirow{2}{*}{$\begin{array}{c}\text { Osnovni } \\
\text { materijal }\end{array}$} & \multicolumn{3}{|c|}{$\begin{array}{c}\text { Zavareni spojevi sa vremenom } \\
\text { halđenja } \mathrm{t}_{8 / 5}[\mathrm{~s}]\end{array}$} & Debljina epruvete [mm] \\
\cline { 2 - 5 } & 5.5 & 8.5 & 18.5 & 6 \\
\hline & $\mathrm{X}$ & & $\mathrm{X}$ & Sa nadvišenjem na vrhu spoja \\
\hline $\mathrm{X}$ & $\mathrm{X}$ & $\mathrm{X}$ & $\mathrm{X}$ & 6 \\
\hline & $\mathrm{X}$ & & & 5 \\
\hline & $\mathrm{X}$ & $\mathrm{X}$ & $\mathrm{X}$ & 4 \\
\hline & $\mathrm{X}$ & & & 3 \\
\hline & & $\mathrm{X}$ & $\mathrm{X}$ & 2 \\
\hline
\end{tabular}

Table 6. Overview on the conducted tensile test and specimen conditions

Tabela 6. Pregled obavljenih zateznih ispitivanja i uslova epruveta

The tensile tests were performed using a $200 \mathrm{kN}$ tensile testing machine and were repeated three times for each specimen condition. The tensile direction was transversal to the weld seam and the rolling direction of the welded sheets.

\section{RESULTS AND DISCUSSION}

\section{Metallography and hardness}

The weld preparation of the single-bevel groove weld does not show a significant influence on the appearance of weld geometry and heat affected zone, see Fig. 3. The soft zone was comparable and symmetrically on both sides of the weld. This could be explained by the fact that the welding was done by single pass welding.

An exemplary result of the hardness measurements (line scan) of the cross section of the weld for $t_{8 / 5}=5.5 \mathrm{~s}$ can be seen in Fig. 3. Hardness loss is constricted to the visible region of the HAZ and can be mainly attributed to transformation softening effects.
Ispitivanje zatezanjem je sprovedeno korišćenjem mašine od $200 \mathrm{kN}$ i ponovljeno je tri puta za svaki uslov epruvete. Pravac zatezanja je poprečni na šav i pravac valjanja zavarene ploče.

\section{REZULTATI I DISKUSIJA}

\section{Metalografija i tvrdoća}

Priprema za zavarivanje jednostranog sučeonog spoja ne pokazuje značajan uticaj na izgled geometrije šava i zone uticaja toplote, videti sl.3. Meka zona je komparativna i simetrična sa obe strane šava. Ovo se može objasniti činjenicom da je zavarivanje izvedeno u jednom sloju.

Primerni rezultat merenja tvrdoće (linija pretraživanja) poprečnog preseka šava za $t_{8 / 5}=5.5 \mathrm{~s}$ može se videti na sl.3. Gubitak tvrdoće je smanjen navidljivi deo ZUT i uglavnom je posledica efekata transformacionog ojačavanja. 


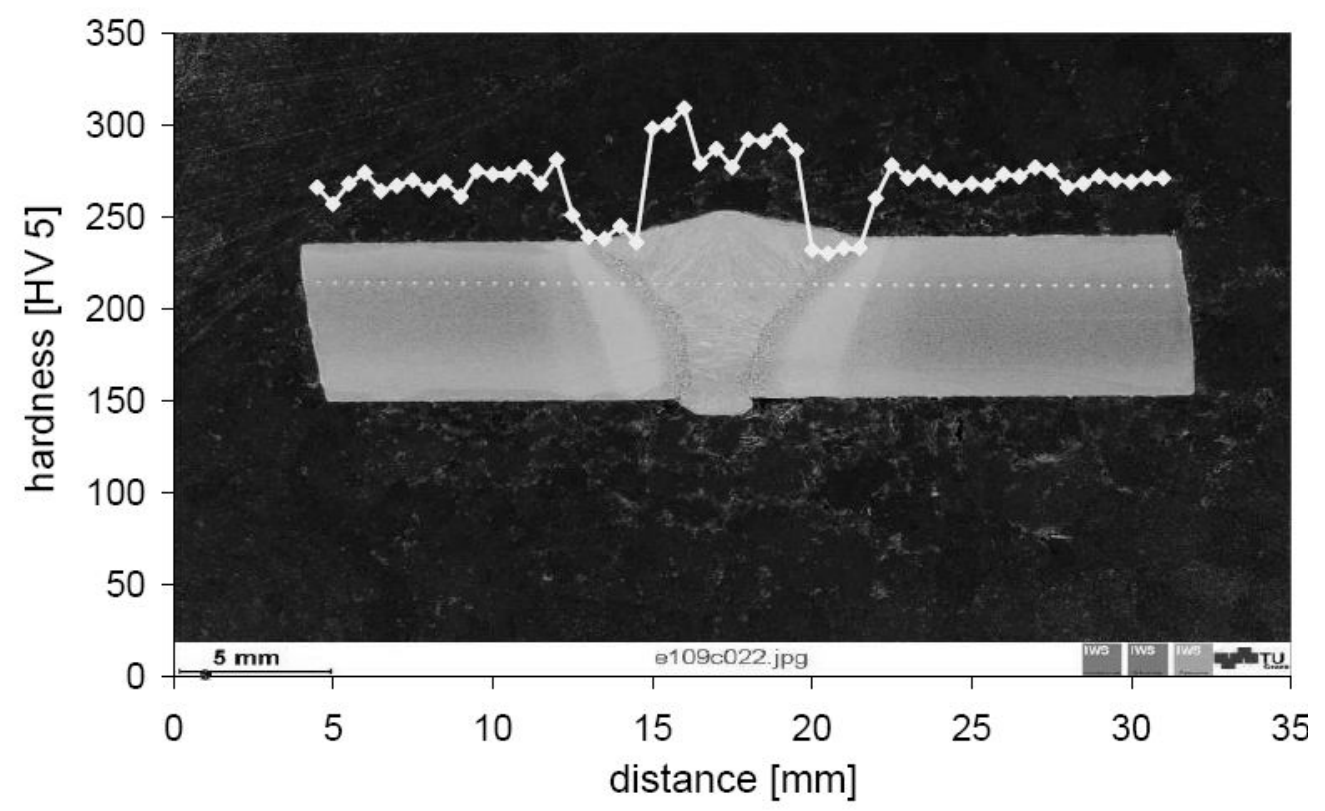

Fig. 3 Results of the Hardness measurements, line distribution for $t_{8 / 5}=5.5 \mathrm{~s}$

SI. 3 Rezultati merenja tvrdoće, linija raspodele za $t_{8 / 5}=5.5 \mathrm{~s}$

Additionally a hardness mapping was carried out over the entire cross sections of the welds to determine the extension of the soft zone as well for the machined samples with reduced thickness. The results for the different cooling times are displayed in Fig. 4.

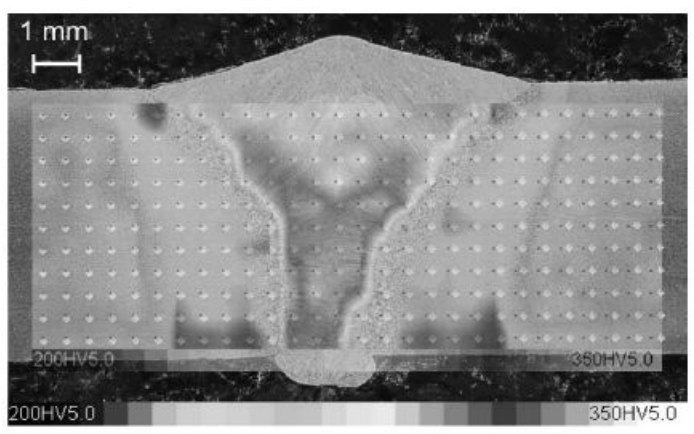

$$
t_{8 / 5}=5.5 \mathrm{~s}
$$

Dodatno je mapa tvrdoća napravljena iznad poprečnog preseka spoja da bi se odredilo proširenje meke zone kao i kod mašinski urađenih uzoraka sa smanjenom debljinom. Rezultati za različita vremena hlađenja su prikazani na sl. 4.

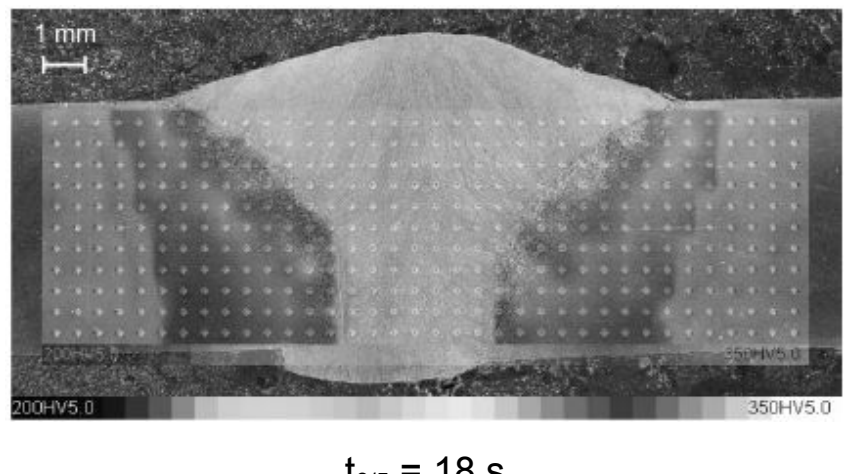

Fig. 4. Result of hardness mapping for three different welding conditions

SI. 4 . Rezultati mapa tvrdoće za tri različita uslova zavarivanja 
The width of the soft zoneswas determined by averaging the results from hardness mapping the results are shown as a function of the cooling time $t_{8,5}$ in Fig. 5 for the sample thickness of $6 \mathrm{~mm}$. The width of the soft zone is nearly linearly increasing with increasing cooling time of which corresponds to observations of Lundin and Mao [26]. Fig. 6 shows the decrease of the hardness of the soft zone and the weld metal with increasing cooling time. Weld metal hardness is more susceptible to increased heat input than the minimum hardness value of the soft zone.
Širina mekih zona je određena preko srednje vrednosti rezultata iz mapa vrednosti tvrdoće. Rezultati su prikazani kao funkcija vremena hlađenja $t_{8,5}$ na sl. 5 . za uzorak debljine $6 \mathrm{~mm}$. Širina meke zone skoro linearno raste sa povećanjem vremena hlađenja što odgovara zapažanjima koje su imali Lundin i Mao [26]. Na sl. 6 je prikazano smanjenje tvrdoće meke zone imetala šava sa povećanjem vremena hlađenja. Tvrdoća metala šava je mnogo osetljivija na povećani unos toplote nego na minimalnu vrednost tvrdoće meke zone.

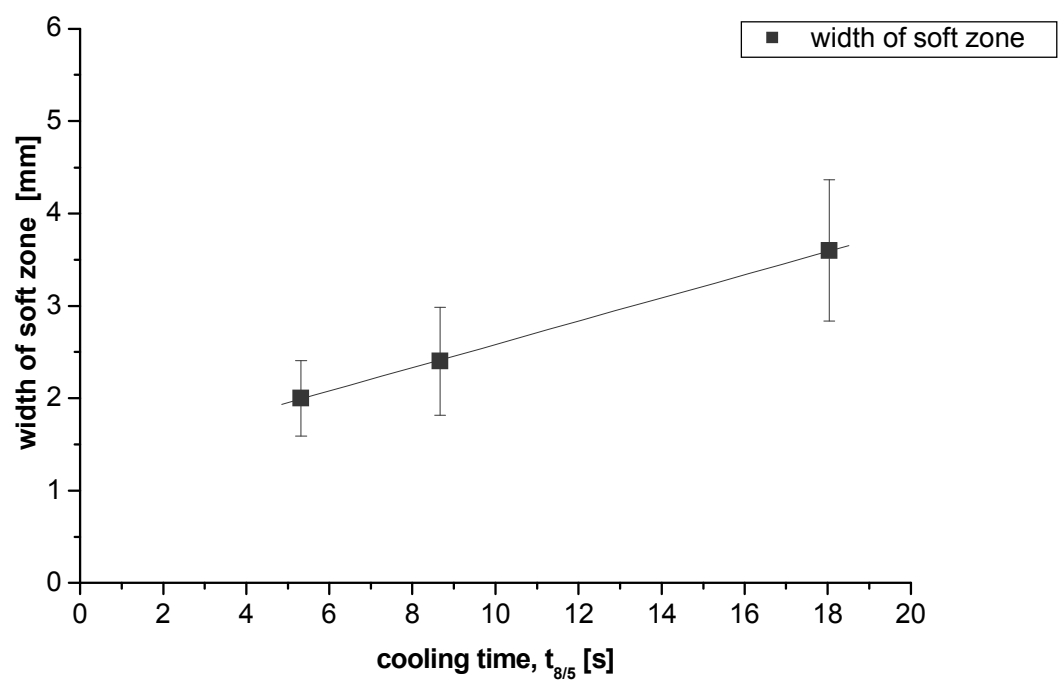

Fig. 5. Width of soft zone as a function of cooling time for sample thickness $6 \mathrm{~mm}$.

Sl. 5. Širina meke zone kao funkcija vremena hlađenja za uzorak debljine $6 \mathrm{~mm}$.

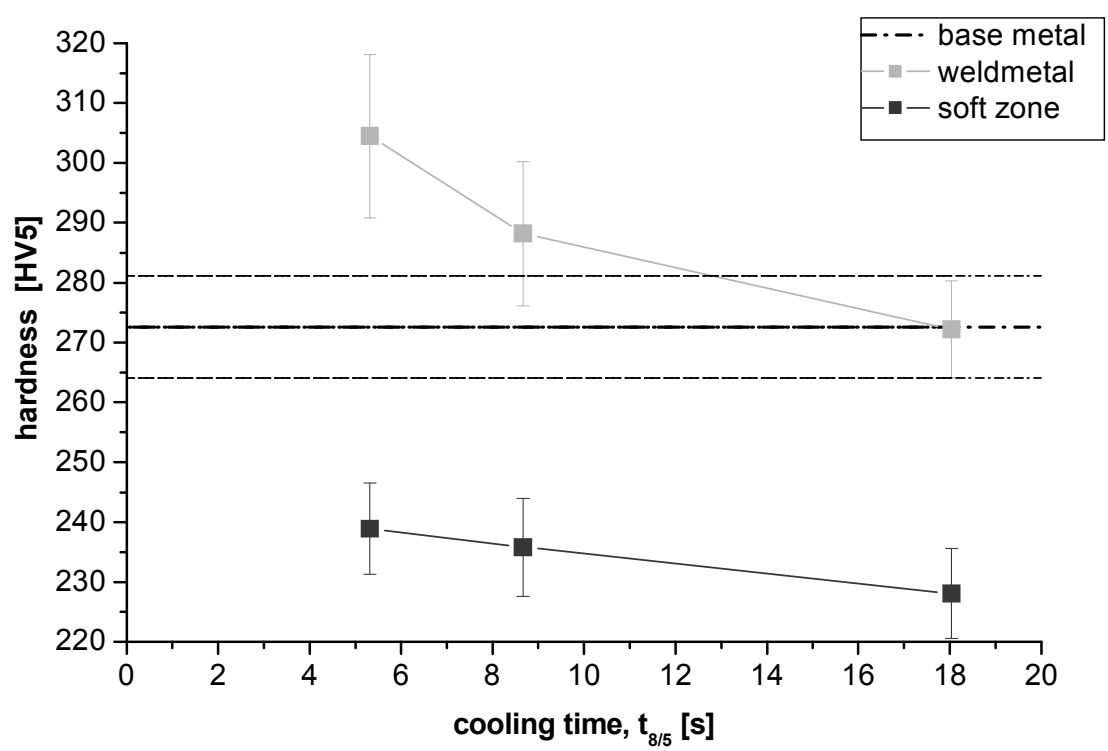

Fig. 6. Hardness values of soft zone and weld metal as a function of the cooling time

SI. 6. Vrednosti tvrdoće meke zone i metala šava kao funkcija vremena hlađenja 
On the basis of Mochizuki [17] two hardness ratios were calculated: softening ratio between base metal and soft zone hardnessand matching ratio between the weld metal and the base metal hardness $\left(H_{W M} / H_{B M}\right)$. In Fig. 7 both ratios are displayed as function of the cooling time $t_{8 / 5}$.
Na bazi tvrdnji Mochizuki [17] izračunata su dva odnosa tvrdoća: odnos omekšavanja između osnovnog materijala i meke zone i odnos slaganja tvrdoća između metala šava i osnovnog materijala $\left(H_{W M} / H_{B M}\right)$. Na sl. 7 data su oba odnosa kao funkcija vremana hlađenja $t_{8 / 5}$.

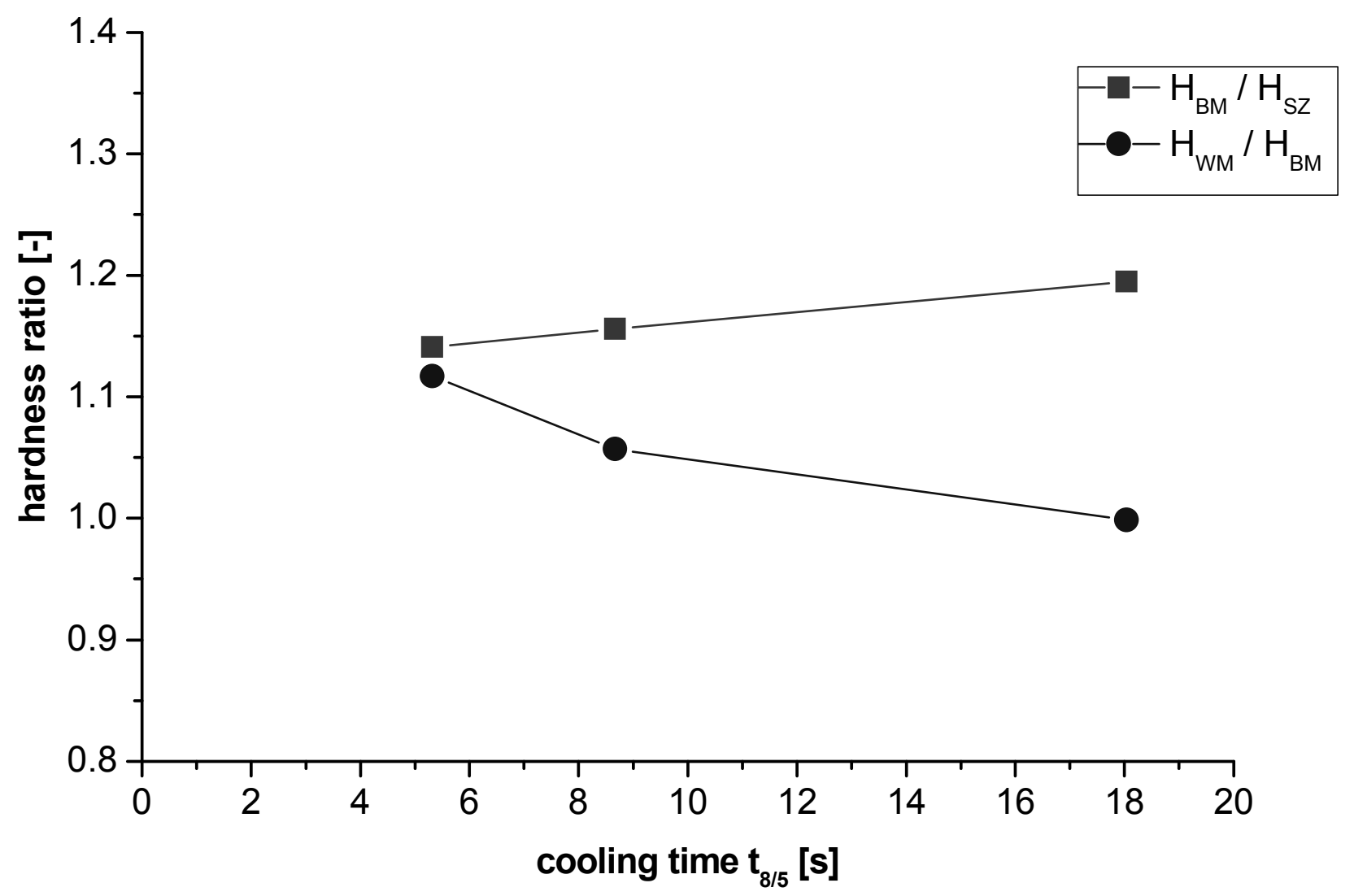

Fig.7. Softening ratio and matching ratio as function of cooling time.

SI. 7. Odnos omekšavanja i odnos podudaranja kao funkcija vremena hlađenja

The strength mismatch between the base and the weld metal changed from over-matching at lower cooling times 5.5 and $8.5 \mathrm{~s}$ to even-matching at cooling time $18 \mathrm{~s}$.

\section{Tensile strength}

The results from the samples with thickness of $6 \mathrm{~mm}$ with and without weld reinforcement are shown in Fig. 8. The measured tensile strength for different samples was related to the relative thickness $X_{S Z}$ of the soft zone. The results of the base metal were presented at $X_{S z}=0$. In addition the specified minimum tensile strength for the investigated steel grade is displayed.
Podudarnost čvrstoća između osnovnog materijala i metala šava se menja od prevelike čvrstoće "overmatching" pri manjim vremenima hlađenja 5.5 i $8.5 \mathrm{~s}$ do podudranja "even-matching" pri vremenu hlađenja $18 \mathrm{~s}$.

\section{Zatezna čvrstoća}

Rezultati sa uzoraka debljine od $6 \mathrm{~mm}$ sa i bez nadvišenja šava, prikazani su na sl. 8. Izmerene zatezne čvrstoće različitih uzoraka su bile u zavisnosti od relativne debljine $X_{S Z}$ meke zone. Rezultati za osnovni materijal su prikazani na $X_{S z}=0$. Dodatno je prikazana minimalna specificirana zatezna čvrstoća za ispitivanu klasu čelika. 


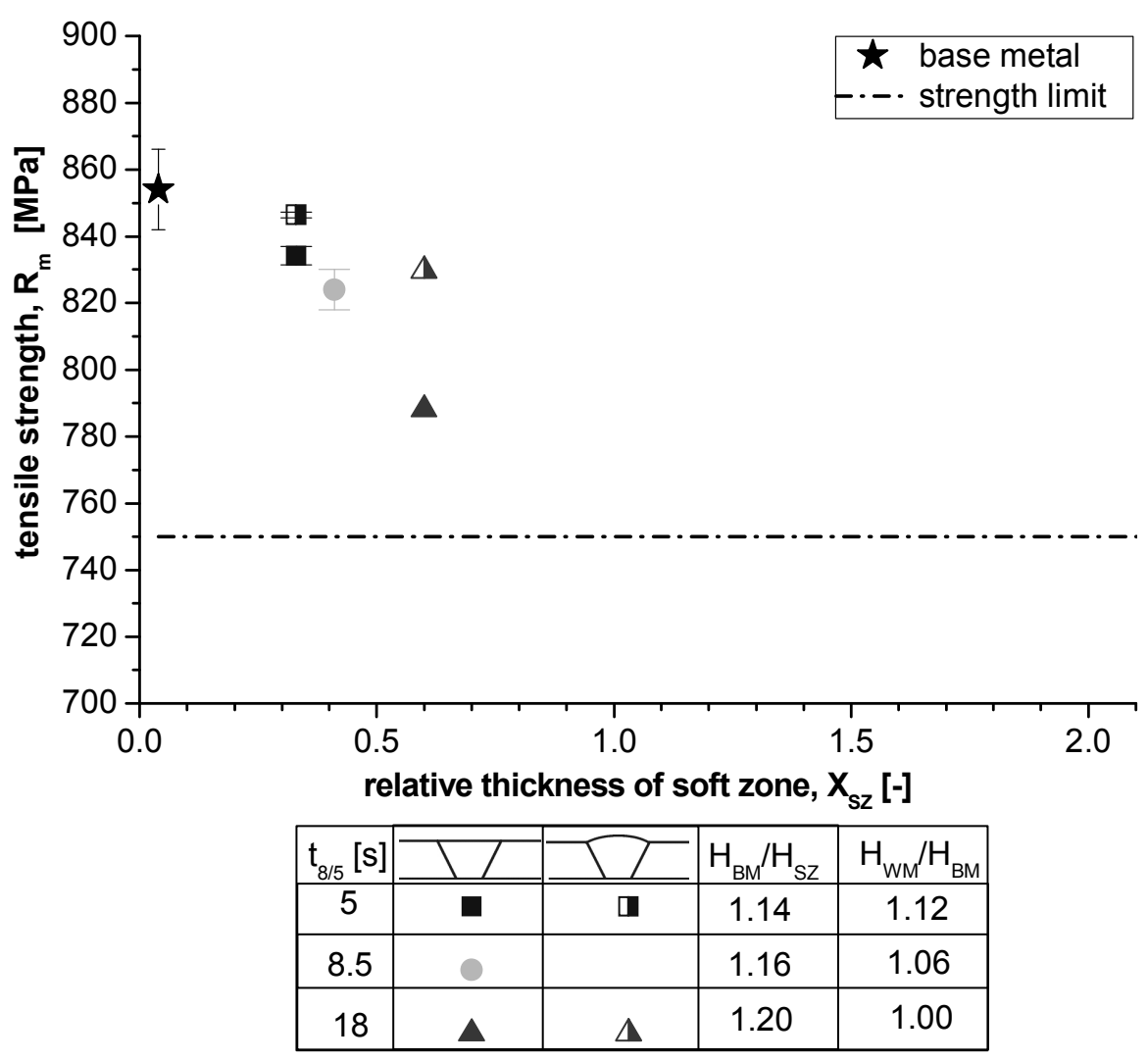

Fig. 8. Tensile strength as a function of relative thickness of soft zone for samples with 6mm thickness.

SI. 8. Zatezna čvrstoća kao funkcija relativne debljine meke zone kod uzoraka debljine $6 \mathrm{~mm}$.

Attention should be paid to the fact that the $X_{S Z}$ values are only related to the reported cooling timesforthe samples with origin thickness of $6 \mathrm{~mm}$. Even at $X_{S z}$ of 2 tensile strength still exceeds the specified strength of $750 \mathrm{MPa}$.

The influence of inherent weld geometry and therefore soft zone and weld metal geometry was not considered in this study. Also the level of hardness reduction and its influence on the static was not quantified separately.

Following the assumptions of Satoh and Toyoda [14] concerning the influence of plate width on the resulting tensile strength, minor reduction of the tensile strength for the samples with sheet thickness $5-6 \mathrm{~mm}$ and $X_{s z}<1$ cannot be excluded. All other samples fulfil the assumptions of infinite plate width.

\section{Fracture behaviour}

All samples showed a ductile fracture behaviour and necking in the HAZ. The location of fracture was for all samples located within the soft zone. Fig. 10 and Fig. 11 show the influence of the weld reinforcement on the fracture appearance at same sample thickness and cooling time.
Treba obratiti pažnju na činjenicu da se vrednosti $X_{S Z}$ odnose samo na saopštena vremena hlađenja kod uzoraka originalne debljine od $6 \mathrm{~mm}$. Čak, pri $X_{S Z}$ od 2, zatezna čvrstoća ostaje na specificiranoj vrednosti od $750 \mathrm{MPa}$.

Uticaj uključene geometrije šava i samim tim, meke zone i geometrije metala šava nije razmatran u ovoj studiji. Takođe, nivo smanjenja tvrdoće i njegov uticaj nastatiku nije odvojeno kvantifikovan.

Praćenjem pretpostavki Satoh i Toyoda [14] a koje se odnose na uticaj širine lima na rezultujuću zateznu čvrstoću, minorno smanjenje zatezne čvrstoće kod uzoraka iz ploče debljina $5-6 \mathrm{~mm}$ i $X_{S Z}<1$ ne može biti isključeno. Svi drugi uzorci ispunjavaju pretpostavke za beskonačnu širinu lima.

\section{Ponašanje vezano za lom}

Svi uzorci pokazuju duktilni tip loma i pojavu "vrata" u ZUT. Lokacija preloma kod svih uzoraka je unutar meke zone. $\mathrm{Na}$ sl. 10 i 11 prikazan je uticaj nadvišenja šava na izgled preloma pri istim debljinama uzoraka i vremenima hlađenja. 

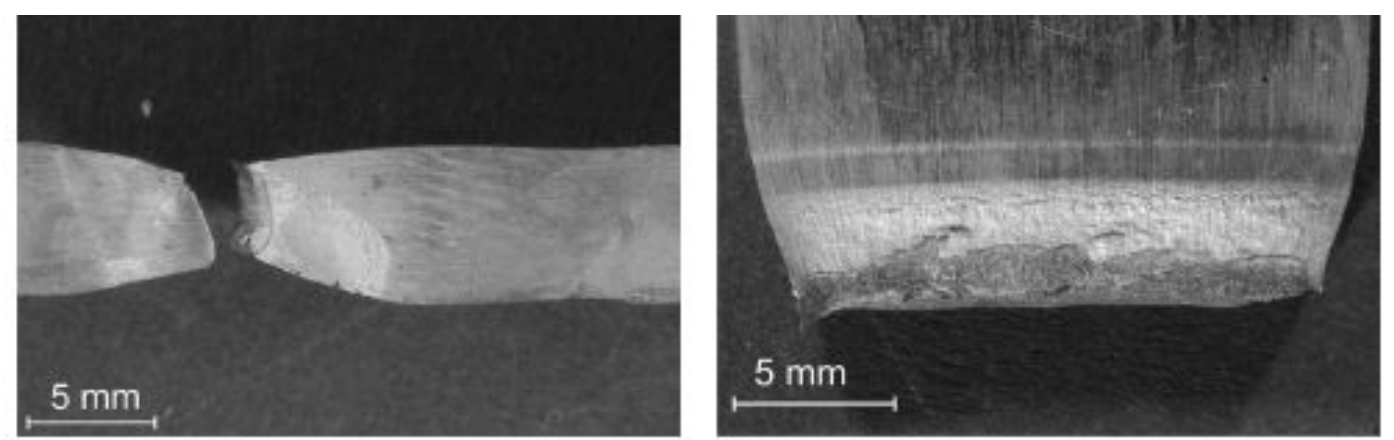

Fig.10. Fracture appearance of sample without weld reinforcement, sample thickness 6mm, cooling time 5.5s.

Sl. 10. Izgled preloma uzorka bez nadvišenja šava, debljina uzorka $6 \mathrm{~mm}$, vreme hlađenja 5.5s.
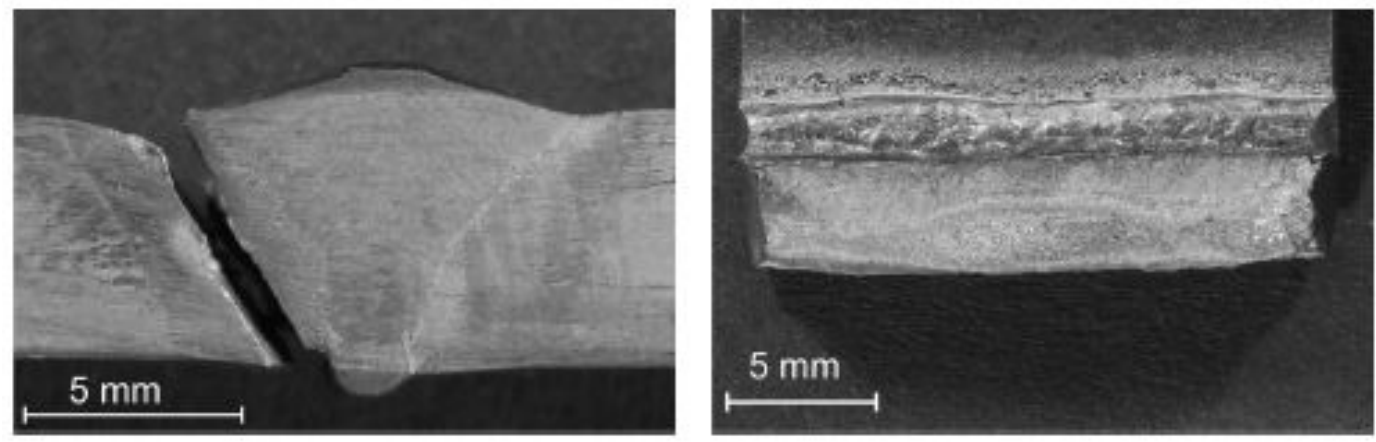

Fig.11. Fracture appearance of a sample with weld reinforcement, cooling time 5.5s.

Sl.11. Izgled preloma uzorka sa nadvišenjem šava, vreme hlađenja $5.5 s$.

The reduced necking in width direction of the samples with weld reinforcement could be attributed to the increased cross section and increased stress triaxiality leading to reduced deformability.

\section{SUMMARY AND OUTLOOK}

This study evaluated the impact of softening in the HAZ on static transversal strength of gas metal arc welds of a TMCP and microalloyed high strength steel strip

The results can be summarized as follows:

$\Rightarrow$ Hardness drop in the HAZ of the welds could be attributed only to transformation softening effects. Hence, the investigated steel does not show tempering softening.

$\Rightarrow$ Weld metal hardness is more susceptible to increased heat input than the minimum hardness value of the soft zone. The matching ratio of the selected weld metal changes from strength over-matching at $5 \mathrm{~s}$ to strength even-matching at $18 \mathrm{~s}$.

$\Rightarrow$ Single pass welds with cooling times of 5 to $18 \mathrm{~s}$ at sheet thickness of $6 \mathrm{~mm}$ cause extension of the soft zone with a relative thickness $X_{S Z}$ between 0.33 and 0.6. The corresponding reduction of tensile strength is restricted to $3-8 \%$ of the base metal strength
Smanjeno istezanje "vrata" u pravcu širine uzoraka sa nadvišenjem šava može se pripisati povećanom poprečnom preseku i povećanom troosnom naponu koji dovode do smanjenja deformabilnosti.

\section{REZIME I PROGNOZA}

Ova studija je ocenila uticaj omekšavanja u ZUTna statičku poprečnu čvrstoću zavarenih spojeva izvedenih u zaštiti gasa od TMCP i mikrolegiranih čelika povišene čvrstoće.

Rezultati se mogu prikazati na sledeći način:

$\Rightarrow$ Pad tvrdoće u ZUT zavarenih spojeva može se pripisati samo efektu transformacionog omekšavanja. Otuda, ispitivani čelik nije pokazao omekšavanje žarenjem.

$\Rightarrow$ Tvrdoća metala šava je mnogo osetljivija na porast količine unete toplote nego na minimalne vrednosti tvrdoće meke zone. Odnos podudarnosti odabranog metala šava se menja od "over-matching" na $5 \mathrm{~s}$ do "even-matching" na 18s.

$\Rightarrow$ Jednoslojni zavreni spojevi sa vremenima hlađenja od 5 do 18s na pločama debljine od $6 \mathrm{~mm}$ uzrokuju proširenje meke zone sa relativnom debljinom $X_{S z}$ između 0.33 i 0.6. Odgovarajuće smanjenje zatezne čvrstoće je ograničeno na 3-8\% čvrstoće osnovnog materijala. 
Tensile strength exceeds the specified strength limit in all cases.

$\Rightarrow$ Up to approximately $X_{S z}=0,25$ the strength level matches the tested strength level of the actual base metal, confirming the minimum criteria defined for conventional steels.

$\Rightarrow$ The width of soft zone increases linearly with the cooling time.

$\Rightarrow$ Weld reinforcement causes an increase in static tensile strength.

$\Rightarrow$ The applied method to reduce the sample thickness by milling is feasible to investigate the constraint effect systematically to increased relative thicknesses of the softzone $X_{S Z \text {. }}$.

$\Rightarrow$ The tensile strength of the investigated welds fell not below the specified tensile strength of the investigated material even up to $X_{S Z}$ of 2 .

HAZ softening dependsmainly on the relative extension of the soft zone andhasonlya small effect on the transverse tensile strength of the joint. The magnitude of this effect is related to the constraints of the uninfluenced base metal as well as the high strength weld metal. Therefore welding processes with reduced energy input per pass are recommended for high strength steels. Selecting a filler material has to consider welding conditions to match the required strength level.

Application of beam welding processes to TMCP steel strips will be the subject of further studies to achieve and investigate relative thicknesses of soft zones below 0.33 .

Physical welding simulation with localized softening will be carried out to exclude the influence of weld metal.
Zatezna čvrstoća prelazi specificiranu granicu čvrstoće u svim slučajevima.

$\Rightarrow$ Do približno $X_{s z}=0,25$ nivo čvrstoće se podudara sa nivoom ispitivanog osnovnog materijala, potvrđujući minimalni kriterijum definisan za konvencionalne čelike.

$\Rightarrow$ Širina meke zone linearno raste sa vremenom hlađenja.

$\Rightarrow$ Nadvišenje šava uzrokuje povećanje statičke zatezne čvrstoće.

$\Rightarrow$ Primenjena metoda za smanjenje debljine uzoraka glodanjem, je izvodljiva kod istraživanja efekta ograničenja prema porastu relativne debljine meke zone $X_{S Z \text {. }}$.

$\Rightarrow$ Zatezna čvrstoća istraživanih zavarenih spojeva ne pada ispod specificirane zatezne čvrstoće istraživanog materijala čak i kada je $X_{S Z} 2$.

Omekšavanje ZUT uglavnom zavisi odrelativnog proširenja mekezone i ima samo mali uticaj na poprečnu zateznu čvrstoću spoja. Veličina ovog efekta je u relaciji sa ograničenjem osnovnog materijala koji nije pod uticajem kao i metala šava od čelika povišene čvrstoće. Zbog toga se preporučuju postupci zavarivanja sa smanjenom količinom unete energije po prolazu(sloju) kod čelika povišene čvrstoće. Izbor dodatnog materijala treba da je zasnovanna uslovima zavarivanja koji treba da zadovolje ispunjenje zahtevanog nivoa čvrstoće.

Primena postupaka zavarivanja snopom na trakama od TMCP čelika će biti subjekat narednih studija kako bi se odredile i istražile meke zone sa relativnim debljinama ispod 0.33 .

Da bi se isključio uticaj metala šava, sprovešće se fizička simulacija zavarivanja sa lokalizovanim omekšavanjem. 


\section{REFERENCES}

[1] M. Klein, H. Spindler, A. Luger, R. Rauch, P. Stiaszny, M. Eigelsberger: Thermomechanically hot rolled high and ultra high strength steel grades processing, properties and application. Materials Scienece Forum Vols 500-501 (2005) 543-550.

[2]B. de Meester: The weldability of modern structural TMCP steels.ISIJ International 37 (1997), no. 6, 537551.

[3] J. G. Youn; H. J. Kim: Characteristics of TMCP steel and its softening. Proc. Int. Sym. on Welding Metallurgy of Structural Steels (1987) p. 157-168.

[4] R. Honeycomb, H. K. D. H. Bhadeshia. Steels microstructure and properties. $2^{\text {nd }}$ edition. 1995. Edward Arnold

[5] F. Wallner: Grundsätzliches zur Schweißeignung wasservegüteter hochfester Al-Si-MnFeinkornbaustähle, Dissertation, Technische Universität Graz.

[6] S.K. Panda, N. Sreenivasan, M. L. Kuntz, Y. Zhou. Numerical simulations and experimental results of tensile test behavior of laser butt welded DP980 steels. Journal of Engineering Materials and Technology, 130 (2008) 041003-1 - 041003-9.

[7] J. Mennen: Schweißen von Vergütungsstählen. In: DVS-Berichte 23 (1962), 18-25.

[8] R. Müller: Probleme beim Schweißen von vergüteten Baustählen. In: DVS-Berichte 46 (1966), S. 54-61

[9] J. Unfried S., C.M. Garzon, J.E. Giraldo. Numerical and experimental analysis of microstructure evolution during arc welding in armor plate steels. Journal of materials processing technology 129 (200) 1688-1700.

[10] R. Denys: The effect of HAZ softening on the fracture characteristics of modern steel weldments and the practical integrity of marine structures made by TMCP steels. In: Proc. EVALMAT 89, vol. 2 (1989), 1013-1027.

[11] F. Wallner, R. Schimböck, R. Rauch: Verbesserte und neue TM-Stähle für geschweißte Konstruktionen, Internationale Schweiß- und Fertigungstechnische Tagung 2000, Wien.

[12] R. Z. Shron, G. A. Bakshi: The problem of gauging the strengths of welded joints in which there is a soft interlayer. In: Welding Production (1962), no. 9, 11-14.

[13] K. Satoh, M. Toyoda: Static tensile properties of welded joints including soft interlayer. In: Transactions of the Japan Welding Society 1 (1970), no. 1, 7-12.
[14] K. Satoh, M. Toyoda: Static strength of welded plates including soft interlayer under tension across a weld line. In: Transactions of the Japan Welding Society 1 (1970), No. 2, 10-17.

[15] A.A. Ostsemin. Stress state and static strength of mechanically inhomogeneous welded joints. Report 1 Evaluating the effect of significant amounts of inhomogeneity on the static strength of welded joints. Strength of materials 23 (1991), no. 4, 398-405.

[16] D.M. Rodrigues, L.F. Menezes, A. Loureiro, J.V. Fernandes. Numerical study of the plastic behaviour in tension of welds in high strength steels. International Journal of Plasticity 20 (2004) 1-18.

[17] M. Mochizuki, T. Shintomi, Y. Hashimoto, M. Toyoda: Analytical study on deformation and strength in HAZ-softened welded joints of fine-grained steels. Welding in the World 48 (2004) no. 9-10, p. 2-12.

[18] K. Satoh, A. Nagai.Fatigue strength of welded bars having a hard or soft interlayer.IIW Doc. XIII-530-69. 1969.

[19] H.G. Pisarski, R.E. Dolby. The significance of softened HAZs in high strength steels. Welding in the World 47 (2003) no. 5-6, 32-40.

[20] EN 10149-2:1995: Hot rolled flat products made of high yield strength steels for cold forming - Part 2: Delivery conditions for thermomechanically rolled steels.

[21] EN ISO 16834:2007: Welding consumables - Wire electrodes, wires, rods and deposits for gas-shielded arc welding of high strength steel.

[22] Delivery conditions for filler metal Union X85, BöhlerSchweißtechnik GmbH.

[23] EN 439:1995: Welding consumables - shielding gases for arc welding and cutting.

[24] ISO 6507-1:2005: Metallic materials - Vickers hardness test - Part 1: Test method.

[25] Metallic materials - Tensile testing - Part 1: Method of test at ambient temperature German version EN 10002-1:2001, version December 2001.

[26] C.D. Lundin, T.P.S. Mao: Heat affected zones in low carbon microalloyed steels. Proc.Recent Trends in Welding Science and Technology (1989), p. 249-256.

[27] EN 1993-1-9:2005: Eurocode 3: Design of steel structures - Part 1-9: Fatigue. 